\title{
PENGEMBANGAN E-KOMIK DENGAN MODEL ADDIE UNTUK MENINGKATKAN MINAT BELAJAR TENTANG PERJUANGAN PERSIAPAN KEMERDEKAAN INDONESIA
}

\author{
I Putu Gde Caesar Renddy Wicaksana', Anak Agung Gede Agung², \\ I Nyoman Jampel ${ }^{3}$ \\ Jurusan IImu Pendidikan Pshikologi dan Bimbingan \\ Prodi Teknologi Pendidikan \\ Universitas Pendidikan Ganesha \\ Singaraja, Indonesia
} e-mail: wicaksana.putu@undiksha.ac. ${ }^{1}$, agung2056@undiksha.ac.id ${ }^{2}$,

\begin{abstract}
Abstrak
Permasalahan yang terjadi di kelas V SD Negeri 5 Kampung baru adalah kurangnya minat belajar siswa pada materi Persiapan Kemerdekaan Indonesia dengan rata-rata hasil pretest minat belajar siswa 26,17 dari nilai maksimal yaitu 70 . Penelitian ini bertujuan untuk (1) Untuk mendeskripsipkan rancang bangun pengembangan media ekomik, (2) Untuk mendeskripsikan hasil validasi pengembangan media e-komik, (3) Untuk mengetahui efektifitas media e-komik dengan model ADDIE untuk meningkatkan minat belajar siswa tentang perjuangan persiapan kemerdekaan indonesia di kelas $\mathrm{V}$ SD Negeri 5 Kampung Baru. Analisis data menggunakan analisis deskriptif kualitatif, kuantitatif dan statistik inferensial / induktif uji-t dan model pengembangan yang digunakan adalah model $A D D I E$. Validitas media telah diuji coba kepada ahli desain pembelajaran, media pembelajaran, uji coba perorangan, kelompok kecil dan uji coba lapangan Untuk hasil validitas pengembangan media e-komik untuk ahli desain pembelajaran, ahli media pembelajaran, uji coba perorangan, uji coba kelompok kecil dan uji coba lapangan secara berurutan yaitu 95,83\%, 92,75\%, 95\%, 93,05\%, dan $91,30 \%$. Hasil uji efektivitas yang dianalisis dengan teknik statistik inferensial (uji-t) mendapatkan hasil rata-rata pretest $(26,17)<$ hasil rata-rata posttest $(63,96)$. Setelah dilakukan perhitungan secara manual dengan menggunakan uji-t didapatkan hasil yang menunjukkan thitung $(51,49)>$ dari ttabel $(2,45)$ sehingga $\mathrm{HO}$ ditolak dan $\mathrm{H} 1$ diterima artinya Terdapat efektivitas dalam pemanfaatan E-komik Model ADDIE Tentang Persiapan Kemerdekaan Indonesia pada materi Persiapan Kemerdekaan Indonesia kelas V di SD Negeri 5 Kampung Baru tahun ajaran 2018/2019.
\end{abstract}

Kata-kata kunci: pengembangan, e-komik, minat belajar

\begin{abstract}
The aim of this result is about the problem in V class at SD Negeri 5 Kampung Baru is the lack of interest in learning of preparation for Indonesian independence with the result in pretest with average 26,17 from the maximal is 70 . The aim of this result is (1) to describe the development of e-comic design, (2) to describe the validation result about the development of media e-comic design, (3) to know about the effectiveness of media e-comic with ADDIE model to increase the lack of learning about fighter of freedom in Indonesian in V class SD Negeri 5 Kampung baru. The analysis data using descriptive quantitative, qualitative and statistic inferensial/ inductive t-test and the development design using ADDIE design. The validation media already trying for the expert of the learning design, learning design, individual trials, small group and field trials for the validity result of the development of the e-comic design for the expert learning design, the expert learning design, individual trials, small group trial and field trials with the sequence is $95,83 \%, 92,75 \%, 95 \%, 93,05 \%$ and $91,30 \%$. The result of the effectivity with the analysis in statistic technique inferential (ttest) is $(26,17)<$ the average posttest result $(63,96)$. After manual counting with t-test the result is $(51,49)$
\end{abstract}


>from ttable $(2,45)$ so that $\mathrm{Ho}$ rejected and $\mathrm{H}_{1}$ accepted means there is activities in utilization E-comic models ADDIE about the preparation indonesian independent $\mathrm{V}$ class at SD Negeri 5 Kampung baru 2018/2019

Keywords: development, e-comic, interest to learn

\section{PENDAHULUAN}

Teknologi pendidikan bertujuan untuk memecahkan permasalahan yang ada dalam pembelajaran dan diharapkan memberikan banyak manfaat dalam upaya meningkatkan kualitas dan juga efektifitas pembelajaran. Association for Educational communication and Technology (AECT) (dalam Erwinsyah, 2015:14) menyatakan Teknologi Pendidikan dalam arti luas adalah "proses yang kompleks dan terpadu yang melibatkan orang, prosedur, ide, peralatan dan organisasi untuk menganalisis masalah, mencari problem solving, melaksanakan evaluasi dan mengelola pemecahan masalah yang menyangkut semua aspek belajar manusia".

Lebih spesifiknya definisi Teknologi Pendidikan dari AECT Tahun 2008 (dalam Mukminan, 2012:4) menyatakan bahwa: "Educational Technology is the study and ethical practice of facilitating learning and improving performance by creating, using, and managing appropriate technological process and resources". Artinya Teknologi Pendidikan adalah studi dan etika praktik dalam rangka memfasilitasi belajar dan peningkatan kinerja melalui penciptaan, penggunaan, dan pengelolaan proses dan sumber-sumber secara memadai. Berdasarkan definisi AECT di atas, Definisi 2008 sudah lebih spesifik karena menekankan pada studi dan praktik. Dalam rangka memfasilitasi belajar, seorang teknolog pembelajaran haruslah bisa memecahkan masalah dalam pembelajaran dengan mempraktekkan apa yang telah di pelajari selama ini, misalnya saja membuat media pembelajaran untuk memecahkan masalah dalam pembelajaran ataupun membantu mencapai tujuan pembelajaran.
Salah satu masalah dalam pembelajaran kurangnya minat belajar siswa karena kurang menariknya kegiatan belajar mengajar di kelas maupun media pembelajaran di gunakan oleh guru di kelas. Seperti yang sudah kita ketahui, menciptakan kegiatan belajar mengajar yang menarik di kelas masih menjadi masalah bagi hampir sebagian besar guru. Tentu saja guru maupun pihak lainnya sudah berusaha untuk menjawab permasalahan ini. Siswa pada zaman ini cenderung santai dan juga tidak peduli, sehingga guru sangat susah menarik perhatian siswa untuk terlibat dalam pembelajaran

Minat belajar terdiri dari 2 kata, minat dan belajar. minat merupakan rasa ketertarikan, perhatian, keinginan lebih yang dimiliki seseorang terhadap suatu hal, tanpa ada dorongan. Hilgard (dalam Slameto, 2010: 57) berpendapat bahwa minat adalah kecenderungan untuk bertahan untuk memperhatikan dan menikmati beberapa aktivitas atau konten. Sedangkan menurut Slameto (2010: 180) "minat adalah suatu rasa lebih suka dan rasa ketertarikan pada suatu hal atau aktivitas, tanpa ada yang menyuruh".

Belajar menurut Slameto (2010:2) belajar ialah suatu proses usaha yang lakukan seseorang untuk memperoleh suatu perubahan tingkah laku yang baru secara keseluruhan, sebagai hasil pengalaman yang diperoleh sendiri dalam interaksi dengan lingkungannya. Menurut Whittaker (dalam Djamarah, 2002:12) merumuskan bahwa "belajar sebagai proses dimana tingkah laku ditimbulkan atau diubah melalui latihan atau pengalaman". Demikian pula menurut Djamarah (2002: 13) belajar adalah "serangkaian kegiatan jiwa raga untuk memperoleh suatu perubahan tingkah laku 
sebagai hasil dari pengalaman individu dalam interaksi dengan lingkungannya yang menyangkut kognitif, afektif dan psikomotor".

Berdasarkan definisi-definisi di atas dapat dipahami bahwa minat belajar merupakan suatu perasaan senang melakukan suatu proses perubahan tingkah laku yang ditampilkan oleh seorang siswa dalam bentuk perhatian yang terus menerus dan juga perasaan senang. Dengan kata lain minat belajar itu adalah perhatian, rasa suka, ketertarikan seseorang (siswa) terhadap belajar yang ditunjukkan melalui keantusiasan, partisipasi dan keaktifan dalam belajar.

Antara materi, guru, strategi, media dan siswa menjadi rangkaian mutual yang saling mempengaruhi sesuai kedudukan masing-masing dalam pembelajaran. Pembelajaran yang optimal harus didukung masing-masing komponen dalam pembelajaran itu sendiri. Agustiningsih (2015:180) mengatakan kehadiran media dalam pembelajaran juga dikatakan dapat membantu peningkatan pemahaman siswa, penyajian informasi lebih menarik dan terpecaya, memudahkan penafsiran data, dan memadatkan informasi. Jadi dalam hal ini di katakan bahwa fungsi media teknologi adalah sebagai sarana bantu dalam proses pentransferan ilmu pengetahuan ataupun informasi dalam pembelajaran. Media pembelajaran yang cocok dikembangkan untuk siswa saat ini E-komik. E-komik yang dimaksud adalah media visual yang dikemas dalam bentuk audiovisual yang di operasikan atau digunakan di. E-komik berasal dari kata komik yang merupakan suatu bentuk seni yang menggunakan gambar-gambar tidak bergerak disusun sebagian rupa, hingga membentuk jalannya cerita.

Jadi, tujuan dari penelitian pengembangan ini adalah (1) Untuk mendiskripsikan rancang bangun pengembangan media e-komik dengan model ADDIE untuk meningkatkan minat belajar siswa tentang perjuangan persiapan kemerdekaan indonesia di kelas $\mathrm{V} S \mathrm{SD}$ Negeri 5 Kampung Baru. (2) Untuk mendiskripsikan hasil validasi pengembangan media e-komik dengan model ADDIE untuk meningkatkan minat belajar siswa tentang perjuangan persiapan kemerdekaan indonesia di kelas $\mathrm{V} S \mathrm{SD}$ Negeri 5 Kampung Baru. (3) Untuk mengetahui efektifitas Media media e-komik dengan model ADDIE untuk meningkatkan minat belajar siswa tentang perjuangan persiapan kemerdekaan indonesia di kelas $\mathrm{V}$ SD Negeri 5 Kampung Baru.

\section{METODE}

Penelitian ini dilaksanakan pada kelas V semester Genap di SD N 5 Kampung Baru. Subjek dalam penelitian ini adalah seluruh siswa kelas $\mathrm{V}$ yang berjumlah 23 orang siswa.

Model pengembangan yang di gunakan dalam pengembangan produk ini adalah Model ADDIE. Adapun tahapan dari model ini menurut Lynch \& Roecker (dalam Mahadewi \& Sukmana, 2015;83-84) yaitu: (1) Analisis (Analysis), (2) Desain (Design), (3) Pengembangan (Development), (4) Penerapan ( Implementation), (5) Evaluasi (Evaluation). Pemilihan model ADDIE dikarenakan model ADDIE sudah dipahami oleh pengembang, selain itu model ADDIE tidak terlalu kompleks.

Pada tahap analisis (Analysis) disimpulkan kurangnya media pembelajaran yang di gunakan guru dalam menyampaikan materi dan banyaknya materi yang harus dipahami dan diingat oleh siswa menyebabkan kurangnya minat dalam mengikuti pembelajaran di kelas. Berdasarkan kesimpulan dari analisis diatas, maka perlu dikembangkan media e-komik pada materi persiapan kemerdekaan Indonesia guna meningkatkan minat belajar siswa. 


\section{Pada tahap perancangan (Design) telah dikembangkan storyboard berdasarkan buku ajar siswa itu pada tahap ini juga ditentukan software yang akan digunakan saat pengembangan.}

Selanjutnya ada pengembangan (Development) yang merupakan proses mewujudkan Storyboard menjadi kenyataan menggunakan software yang telah ditentukan pada tahap desain. Saat melalui tiap tahap ada evaluasi dan revisi yang dilakukan demi perbaikan produk yang dihasilkan.

Tahap implementasi ini dilakukan penerapan di SD Negeri 5 Kampung Baru dengan tujuan agar dapat memberikan pengaruh yang signifikan atau tidak terhadap minat belajar siswa. Sebelum melakukan implementasi di kelas, terlebih dahulu dilakukan uji ahli guna mengetahui respon ahli. Tahap ini bertujuan untuk mengetahui respon ahli media pembelajaran dan siswa dari segi kemenarikan dan kelayakannya. Hasil implementasi berupa validasi yang dilakukan oleh ahli media pembelajaran untuk uji coba produk meliputi (a) uji perorangan yang melibatkan 3 (tiga) orang siswa, (b) uji coba kelompok kecil mengikutsertakan 12 (dua belas) orang siswa , (c) Sedangkan uji coba lapangan melibatkan 23 (dua puluh tiga).

Adapun hasil evaluasi formatif yang akan di analisis berupa penilaian dari validasi ahli, uji coba perorangan, kelompok kecil, dan lapangan, sehingga didapatkan perbaikan produk. Sedangkan hasil evaluasi sumatif dilakukan guna mengetahui efektivitas produk yang dikembangkan dalam meningkatkan minat belajar siswa dengan melakukan tahap uji efektivitas.

Data yang dikumpulkan melalui pelakasanaan evaluasi formatif dikelompokkan menjadi tiga bagian, yaitu: (1) data hasil review ahli desain pembelajaran, data hasil review ahli media pembelajaran, (2) data dari evaluasi tahap kedua berupa data hasil review uji coba perorangan, data hasil review uji coba kelompok kecil, hasil review uji coba lapangan dan (3) data dari hasil uji efektivitas media e-komik perjuangan persiapan kemerdekaan Indonesia.

Produk media pembelajaran berupa media e-komik perjuangan persiapan kemerdekaan Indonesia sebagai hasil dari penelitian pengembangan ini diuji validitas dan keefektifannya. Validitas media pembelajaran diketahui melalui analisis kegiatan uji coba yang dilaksanakan melalui beberapa tahap, yakni: (a) review oleh ahli desain pembelajaran, dan ahli media pembelajaran, (b) uji coba perorangan, (c) uji coba kelompok kecil, dan (d) uji coba lapangan. Tingkat keefektifan media pembelajaran diketahui melalui penyebaran angket siswa pada saat uji lapangan. Hasil angket yang diperoleh akan dianalisis menggunakan rubrik yang sudah dirancang.

Metode yang digunakan dalam penelitian ini yaitu metode kuesioner. Menurut Agung (2014:99) "metode kuesioner adalah cara memperoleh atau mengumpulkan data dengan mengirimkan suatu daftar pertanyaan/ pernyataanpernyataan kepada responden/subjek penelitian". Tapi pada tahap ini angket/kuesioner akan digunakan untuk mengumpulkan data hasil review dari ahli desain pembelajaran, ahli media pembelajaran, siswa saat uji coba perorangan, siswa saat uji coba kelompok kecil dan siswa saat uji lapangan.

Penelitian pengembangan ini menggunakan tiga teknik analisis data, yaitu teknik analisis deskriptif kualitatif, analisis deskriptif kuantitatif dan analisis statistik inferensial. Menurut Agung (2014:250) Teknik analisis deskriptif kuantitatif ialah suatu cara pengolahan data yang dilakukan dengan jalan menyusun secara sistematis dalam bentuk angka-angka dan atau persentase, mengenai suatu objek yang diteliti. sehingga diperoleh kesimpulan umun. Teknik analisis ini digunakan untuk 
mengolah data yang diperoleh melalui angket dalam bentuk deskriptif persentase. Rumus yang digunakan untuk menghitung presentase dari masing-masing subjek adalah :

Persentase $=\frac{\sum(\text { Jawaban } \times \text { bobot tiap pilihan })}{n \times \text { bobot tertinggi }} \times 100 \%$

Keterangan:

$\Sigma:$ Jumlah

$\mathrm{n}$ : jumlah seluruh item angket
Selanjutnya, untuk menghitung persentase keseluruhan subjek digunakan rumus:

Keterangan:

$$
\text { Persentase }=\frac{F}{N}
$$

$\mathrm{F}=$ jumlah persentase keseluruhan subjek

$\mathrm{N}$ = banyak subjek

Untuk dapat memberikan makna dan pengambilan keputusan digunakan keterangan sebagai berikut. (tabel 0.1)

Tabel 0.1 Konversi Tingkat Pencapaian dengan Skala 5

\begin{tabular}{ccc}
\hline Tingkat pencapaian & Kualifikasi & Keterangan \\
\hline $90-100$ & Sangat baik & Tidak perlu direvisi \\
$75-89$ & Baik & Tidak perlu direvisi \\
$65-74$ & Cukup & Direvisi \\
$55-64$ & Kurang & Direvisi \\
$0-54$ & Sangat kurang & Direvisi \\
& Sumber :Tegeh dan Kirna (dalam Agung, 2014:251)
\end{tabular}

Koyan (2012:4) menyatakan analisis statistik inferensial adalah statistik yang digunakan untuk. menganalisis data sampel dan hasilnya akan digeneralisasikan diinferensikan kepada populasi dimana sampel itu diambil. Sementara menurut Agung (2014:68) menyatakan "metode analisis statistik inferensial ialah suatu cara pengolahan data yang dilakukan dengan jalan menerapkan rumus- rumus statistik inferensial untuk menguji suatu hipotesis penelitian yang diajukan peneliti, dan kesimpulan ditarik berdasarkan hasil pengujian terhadap hipotesis". Analisis statistik inferensial ini digunakan untuk mengetahui tingkat efektivitas produk terhadap meningkatkan minat belajar pada sebelum dan sesudah menggunakan Ekomik.

Teknik analisis yang digunakan untuk pengujian hipotesis adalah teknik analisis uji-t berkorelasi atau dependen. Dasar penggunaan teknik uji-t berkorelasi ini adalah menggunakan dua perlakuan yang berbeda terhadap satu sampel. Pada penelitian ini akan menguji perbedaan minat belajar sebelum dan sesudah menggunakan E-komik. Pengujian hipotesis dilakukan dengan analisis uji-t berkorelasi. Analisis uji$\mathrm{t}$ berkorelasi memerlukan beberapa persyaratan antara lain melakukan uji normalitas sebaran dan uji homogenitas varian.

Uji normalitas dilakukan untuk mengetahui apakah sebaran skor pada setiap variabel berdistribusi normal atau tidak, untuk itu dapat digunakan Uji Liliefors. Koyan (2012 : 108) menyatakan, Tentukan nilai $L 0=|F(z)-S(z)|$, hitung selisihnya, kemudian bandingkan dengan nilai Lt dari tabel Liliefors. Jika LO< Lt maka HO diterima, sehingga dapat disimpulkan bahwa sampel berasal dari populasi yang berdistribusi normal.

Uji homogenitas ini dilakukan untuk mencari tingkat kehomogenan secara dua pihak yang diambil dari kelompok-kelompok terpisah dari satu populasi yaitu kelompok kontrol dan kelompok eksperimen. Untuk menguji homogenitas varians untuk kedua kelompok digunakan uji Fisher (F), sebagai berikut:

$$
F=\frac{\text { Varian terbesar }}{\text { Varian terkecil }}
$$


Kriteria pengujian $\mathrm{H}_{0}$ diterima jika $\mathrm{F}_{\text {hitung }}$ $<F_{\text {tabel }}$ yang berarti sampel homogen. Uji dilakukan pada taraf signifikan $5 \%$ dengan derajat kebebasan untuk pembilang $n 1-1$ dan derajat kebebasan untuk penyebut n2 1.

Teknik analisis yang digunakan untuk pengujian hipotesis adalah teknik analisis uji-t berkorelasi atau dependen. Dasar penggunaan teknik uji-t berkorelasi ini adalah menggunakan dua perlakuan yang berbeda terhadap satu sampel. Pada penelitian ini akan menguji perbedaan minat belajar sebelum dan sesudah menggunakan produk multimedia pembelajaran interaktif terhadap satu kelompok. Rumus untuk uji-t berkorelasi adalah sebagai berikut.

$$
t=\frac{\bar{X}_{1}-\bar{X}_{2}}{\sqrt{\frac{s_{1}{ }^{2}}{n_{1}}+\frac{s_{2}{ }^{2}}{n_{2}}-2 r\left(\frac{s_{1}}{\sqrt{n_{1}}}\right)\left(\frac{s_{2}}{\sqrt{n_{2}}}\right)}}
$$

$$
\begin{aligned}
& \text { Keterangan: } \\
& \bar{X}_{1}=\text { rata-rata sampel } 1 \text { (sebelum } \\
& \text { menggunakan media) } \\
& \bar{X}_{2} \quad \text { rata-rata sampel } 2 \text { (sesudah } \\
& \text { menggunakan media) }
\end{aligned}
$$

$$
\begin{array}{cc}
\mathrm{S}_{1}= & \text { simpangan baku sampel } 1 \text { (sebelum } \\
\text { menggunakan media) } & \text { simpangan baku sampel } 2 \text { (sesudah } \\
\mathrm{S}_{2} \quad \begin{array}{c}
\text { menggunakan media) } \\
s_{1}{ }^{2}
\end{array} & \text { varians sampel } 1 \\
s_{2}{ }^{2} & =\text { varians sampel } 2 \\
\mathrm{R} & =\text { korelasi antara dua sampel }
\end{array}
$$

Hasil uji coba dibandingkan ttabel dengan taraf signifikasn 0,05 (5\%) untuk mengetahui adanya efektivitas pada produk media e-komik dengan model ADDIE untuk meningkatkan minat belajar siswa tentang perjuangan persiapan kemerdekaan Indonesia.

\section{HASIL DAN PEMBAHASAN}

Hasil dan pembahasan dari penelitian pengembangan ini adalah :

\section{Hasil}

Pada validitas pengembangan media, dipapakarkan 5 hal pokok yang meliputi validitas media E-komik menurut (1) ahli desain pembelajaran, (2) ahli media pembelajaran, (3) uji coba perorangan, (4) uji coba kelompok kecil, (5) uji coba lapangan. Ke-lima hal pokok tersebut disajikan sesuai dengan data yang diperoleh sebagai berikut. (tabel 0.2)

Tabel 0.2 Hasil Validasi dan Uji Coba

\begin{tabular}{cccc}
\hline No & Subjek Uji Coba & Hasil Validitas (\%) & Kualifikasi persentase \\
\hline 1 & Uji Ahli Desain Pembelajaran & $95,8 \%$ & Tidak perlu direvisi \\
2 & Uji Ahli Media Pembelajaran & $93,7 \%$ & Tidak perlu direvisi \\
3 & Uji Coba Perorangan & $95 \%$ & Tidak perlu direvisi \\
4 & Uji Coba Kelompok Kecil & $93,1 \%$ & Tidak perlu direvisi \\
5 & Uji Coba Lapangan & $91,3 \%$ & Tidak perlu direvisi \\
\hline
\end{tabular}

Uji normalitas data dilakukan memperoleh data hasil uji normalitas pretest tersebut diperoleh $\mathrm{L} 0=0.1366<\mathrm{Lt}=0.1798$ maka dapat disimpulkan bahwa sampel berasal dari populasi yang berdistribusi normal.

Sedangkan hasil dari uji normalitas posttest siswa tersebut diperoleh $\mathrm{L} 0=0.1403$ $<\mathrm{Lt}=0.1798$ jadi dapat disimpulkan bahwa sampel berasal dari populasi yang berdistribusi normal.

Uji homogenitas diperoleh hasil pengujian Fhitung yaitu 1,07 sedangkan untuk Ftabel yaitu 2,05 dengan taraf signifikasi $5 \%$. Jadi dapat disimpulkan bahwa Fhitung < Ftabel sehingga kedua data tersebut memiliki persebaran data yang homogen. 
Pengujian hipotesis dilakukan dengan analisis uji-t sampel berkorelasi Dari hasil ujit yang sudah diperoleh thitung yaitu 51,49 dan ttabel yaitu 2,45 untuk derajat kebebasan (db) yaitu 44 dari taraf signifikan $5 \%$. Hal ini berarti thitung $>$ ttabel sehingga $\mathrm{HO}$ ditolak dan $\mathrm{H} 1$ diterima.

\section{Pembahasan}

Pengembangan E-komik Model ADDIE Tentang Persiapan Kemerdekaan Indonesia ini dilakukan dengan menggunakan metode ADDIE yang meliputi tahap analisis kebutuhan, tahap desain, tahap pengembangan, tahap implementasi dan evaluasi.

Rancang bangun pengembangan Media E-komik Persiapan Kemerdekaan Indoneisa disesuaikan dengan model yang digunakan dalam mengembangkan media ini yaitu model ADDIE dengan tahap-tahap pengembangan produk terdiri dari 5 tahap .

Penelitian tahap pertama ini merupakan langkah analisis Penelitian berangkat dari kegiatan melakukan analisis karakteristik peserta didik, dan melakukan analisis konten yang akan dibuatkan ekomik. Analisis karakteristik siswa dari penelitian ini adalah pada saat proses pembelajaran berlangsung masih di dominasi oleh kegiatan yang berpusat pada guru melalui metode ceramah. Siswa kurang aktif dalam berkomunikasi terkait pembelajaran dan pembelajaran siswa hanya terpacu pada Buku Siswa dan Buku Guru.

Analisis konten ditemukan bahwa siswa masih sulit menguasai materi tentang persiapan kemerdekaan Indonesia di karenakan pada materi tersebut siswa di tuntut untuk banyak menghafal mulai dari tangga kejadian yang terkait periapan kemerdekaan Indonesia, siapa saja tokoh yang terlibat, tempat terjadinya peristiwaperistiwa seputar kemerdekaan Indonesia. Dikarenakan banyak hal yang harus diingat dan di pahami oleh siswa tentu saja menurunkan minat siswa dalam mengikuti pembelajaran.

Tahap kedua adalah desain. Pada tahap ini ditentukan kejadian yang akan dia angkat dalam e-komik ini akan ditentukan berdasarkan buku ajar yang digunakan oleh guru dalam menyampaikan materi tentang persiapan kemerdekaan Indonesia. Pemilihan karakter dalam e-komik ini juga bersumber pada buku ajar yang di gunakan oleh guru di kelas dalam menyampaikan materi. Penggambaran karakter dan tempat peristiwa terjadi menggunakan buku ajar guru sebagai sumber primer. Selain itu peneliti juga mencari sumber lain guna mendukung gambaran karakter pada buku ajar agar materi yang nanti disampaikan dalam e-komik sesuai dan tidak melenceng dari kejadian sebenarnya. Sumber gambar yang digunakan sebagai dalam tahap ini diambil dari film "Battle of Surabaya" karya rumah produksi MSV Pictures dan STMIK Amikom. Selain. Software atau aplikasi yang akan di gunakan, selama pengembangan adalah Adobe Photoshop sebagai aplikasi yang akan digunakan untuk pengolah gambar dan Comic Life 3 sebagai aplikasi untuk menyusun gambar dalam bentuk komik.. Sedangkan untuk mengubah kedalam bentuk program siap pakai, software yang digunakan adalah PageFlip 3D Profesional. PageFlip 3D Profesional adalah sebuah program yang dapat mengubah file berbentuk img dan pdf kedalam bentuk flipbook dengan dasar HTML 5 yang biasa digunakan untuk membuat buku elektronik.

Tahap ketiga adalah pengembangan. Tahapan yang dilalui dalam pengembangan produk adalah sebagai berikut : (1) Proses pertama adalah mewujudkan cerita yang sudah disusun dan dirangkum dari berbagai sumber kedalam bentuk gambar. (2) Tahap selanjutnya adalah mengubah layout komik yang telah diubah dalam bentuk pdf kedalam bentuk program siap pakai dan juga menambahkan sound effect. (3) Pada tahap 
ini terus dilakukan dilakukan evaluasi formatif untuk meninjau perkembangan produk agar sesuai dengan tujuan pengembangan produk.

Tahap keempat adalah implementasi. Sebelum melakukan implementasi di kelas, terlebih dahulu dilakukan uji ahli guna mengetahui respon ahli. Tahap ini bertujuan untuk mengetahui respon ahli media pembelajaran dan siswa dari segi kemenarikan dan kelayakannya. Hasil implementasi berupa validasi yang dilakukan oleh ahli media pembelajaran untuk uji coba produk meliputi (a) uji perorangan yang melibatkan 3 (tiga) orang siswa kelas $\mathrm{V}$, Ketiga siswa ini terdiri dari satu orang siswa yang memiliki minat belajar tinggi, satu orang siswa yang memiliki minat belajar sedang, dan satu orang siswa yang memiliki minat belajar rendah. (b) uji coba kelompok kecil mengikutsertakan 12 (dua belas) orang siswa kelas $\mathrm{V}$, empat orang siswa yang memiliki minat belajar sedang, dan empat orang siswa yang memiliki minat belajar rendah. Sedangkan uji coba lapangan melibatkan 23 (dua puluh tiga) orang kelas $\mathrm{V}$.

Tahap evaluasi, pada tahap ini dilakukan analisis pada hasil evaluasi formatif dan evaluasi sumatif yang terkumpul dari implementasi guna mengevaluasi pengembangan produk dan efektivitas produk dalam meningkatkan minat belajar siswa. Adapun hasil evaluasi formatif yang akan di analisis berupa penilaian darivalidasi ahli, uji coba perorangan, kelompok kecil, dan lapangan, sehingga didapatkan perbaikan produk. Sedangkan hasil evaluasi sumatif dilakukan guna mengetahui efektivitas produk yang dikembangkan dalam meningkatkan minat belajar siswa dengan melakukan tahap uji efektivitas.

Setelah tahap pengembangan media selesai dikerjakan, langkah berikutnya melakukan validitas terhadap media yang dikembangkan. Validitas dilakukan dengan melakukan review dari ahli desain pembelajaran mendapatkan presentase $95,8 \%$, ahli media pembelajaran mendapatkan presentase 93,7 \%, uji perorangan mendapatkan presentase $95 \%$, uji kelompok kecil $93,1 \%$, dan uji lapangan mendapatkan presentase $91,3 \%$ sehingga tidak ada yang perlu dilakukan revisi.

Hasil validasi yang didapat secara keseluruhan berada pada kategori sangat baik sehingga tidak perlu direvisi secara besar-besaran. Hal ini di dapat dicapai dengan selalu memperhatikan prinsipprinsip desain visual dalam pengembangan E-komik. Ada 8 prinsip-prinsip desain visual menurut Mayer dan Moreno (Sudarma, d.k.k., 2015:68) yaitu (1) prinsip multimedia, (2) prinsip kedekatan ruang, (3) prinsip kedekatan tempo, (4) prinsip koherensi, (5) prinsip modalitas, (6) prinsip redudansi, (7) prinsip personalisasi, dan (8) prinsip iteraktivitas.

Prinsip multimedia artinya pembelajar akan lebih mudah belajar ketika pesan pembelajaran disajikan menggunakan katakata dan gambar daripada hanya gambar saja.

Prinsip kedekatan ruang artinya pembelajar akan lebih mudah menginterpretasikan pesan ketika sajian teks berdekatan dengan gambar daripada berjauhan dengan gambar.

Prinsip kedekatan tempo atau waktu. Yang dimaksudkan dengan kedekatan tempo adalah pembelajar akan lebih mudah memproses informasi ketika kata-kata (teks atau narasi) dan gambar (gambar diam atau animasi) di sajikan dalam waktu yang bersamaan daripada disajikan dalam waktu yang terpisah atau waktu yang berbeda.

Prinsip koherensi memberikan landasan pengembangan media presentasi bahwa pembelajar dapat belajar lebih optimal ketika kata-kata dan gambar memiliki keselarasan dan pendidik harus berani membuang gambar yang tidak relevan.

Prinsip modalitas artinya pembelajar dapat lebih mudah ketika kata dan gambar 
disajikan dalam pengindraan yang berbeda. Maksudnya pesan pembelajaran lebih baik disajikan dengan animasi dan narasi daripada narasi dan teks.

Prinsip redudansi berasan dari kata redudansi yang artinya berlebihan atau ganda. Jadi Prinsip redudansi yaitu menghindari tipe sajian pesan secara berlebihan.

Prinsip personalisasi artinya pembelajar dapat belajar lebih optimal ketika pesan (kata-kata lisan maupun tulisan) disampaikan secara komunikatif dari pada gaya formal.

Prinsip interaktivitas mengasumsikan bahwa pembelajar dapat belajar lebih baik ketika ia mengendalikan sendiri apa yang sedang apa yang sedang dipelajari atau dapat diartikan pembelajar diizinkan mengendalikan multimedia sesuai kecepatan belajarnya.

Uji normalitas data dilakukan untuk menyajikan bahwa sampel benar-benar berasal dari populasi yang berdistribusi normal. Uji normalitas data dilakukan terhadap 23 siswa kelas 5 SD Negeri 5 Kampung Baru yang diperoleh dari dua tahap yaitu: (1) Pretest, hasil minat belajar siswa sebelum menggunakan E-komik Model ADDIE Tentang Persiapan Kemerdekaan Indonesia dan (2) Posttest, hasil minat belajar siswa sedudah meggunakan E-komik Model ADDIE Tentang Persiapan Kemerdekaan Indonesia. Uji normalitas data dilakukan perhitungan dengan menggunakan teknik Liliefors, diperoleh $\mathrm{Lo}<\mathrm{Lt}$ dengan taraf signifikan 5\%. Dengan demikian semua data skor hasil minat belajar siswa mata pelajaran Tematik berdistribusi normal.

Uji homogenitas dilakukan di kelas 5 sebagai sampel uji efektivitas produk. Data yang digunakan untuk uji homogenitas yaitu hasil minat belajar siswa pretest dan posttest. hasil pengujian Fhitung yaitu 1,07 sedangkan untuk Ftabel yaitu 2,05 dengan taraf signifikasi $5 \%$. Jadi dapat disimpulkan bahwa Fhitung < Ftabel sehingga kedua data tersebut memiliki persebaran data yang homogen.

Berdasarkan hasil pengujian normalitas dan homogenitas diperoleh bahwa data berdistribusi normal dan homogen. Berdasarkan hal tersebut, langkah selanjutnya yaitu uji hipotesis dengan menggunakan uji t-test. Pengujian hipotesis dilakukan dengan analisis uji-t sampel berkorelasi. Semua pengujian hipotesis dilakukan pada taraf signifikansi $5 \%$. Kriteria pengujian adalah apabila hasil perhitungan diperoleh nilai thitung $>$ ttabel maka $\mathrm{Ho}$ ditolak dan $\mathrm{H} 1$ diterima.

Dari hasil uji-t yang sudah diperoleh thitung yaitu 51,49 dan ttabel yaitu 2,45 untuk derajat kebebasan (db) yaitu 44 dari taraf signifikan 5\%. Hal ini berarti thitung > ttabel sehingga $\mathrm{Ho}$ ditolak dan $\mathrm{H} 1$ diterima.

Berdasarkan kriteria pengujian, $\mathrm{H}_{0}$ ditolak dan $\mathrm{H}_{1}$ diterima yang artinya Terdapat efektivitas dalam pemanfaatan Ekomik Model ADDIE Tentang Persiapan Kemerdekaan Indonesia pada materi Persiapan Kemerdekaan Indonesia kelas $\mathrm{V}$ di SD Negeri 5 Kampung Baru tahun ajaran 2018/2019.

Selain meningkatkan minat belajar, Ekomik persiapan kemerdekaan indonesia ini selain meningkatkan minat belajar, E-komik ini juga telah memenuhi 7 peran media visual dalam pembelajaran. Smaldino (Sudarma, d.k.k., 2015:66) menyatakan media visual dalam pembelajaran memiliki 7 peran yaitu (1) menyediakan acuan yang kongkret bagi gagasan, (2) membuat pesan abstrak menjadi kongkret, (3) visual mampu memotivasi pembelajar, (4) visual mampu mengarahkan perhatian, (5) visual mampu mengirangi informasi, (6) visual mampu mengingatkan kembali pembelajaran sebelumnya, dan (7) visual mampu mengurangi usaha belajar. 


\section{SIMPULAN DAN SARAN}

Hasil penelitian ini memiliki beberapa implikasi yang dijabarkan sebagai berikut. Pertama,secara data nyata terbukti bahwa menggunakan E-komik Model ADDIE Tentang Persiapan Kemerdekaan Indonesia berpengaruh baik terhadap hasil minat belajar siswa di dalam kelas.

Kedua, rata-rata hasil minat belajar siswa mempelajari materi persiapan kemerdekaan indonesia setelah menggunakan E-komik Model ADDIE Tentang Persiapan Kemerdekaan Indonesia lebih tinggi dibandingkan rata-rata hasil minat belajar siswa sebelum menggunakan E-komik Model ADDIE Tentang Persiapan Kemerdekaan Indonesia. Berdasarkan hal tersebut, maka E-komik Model ADDIE Tentang Persiapan Kemerdekaan Indonesia dapat diterapkan dalam pembelajaran materi persiapan kemerdekaan indonesia di sekolah yang lain sebagai upaya untuk meningkatkan minat belajar siswa yang masih dianggap rendah.

Ketiga, untuk pengembangan ilmu. Ekomik Model ADDIE Tentang Persiapan Kemerdekaan Indonesia dapat dikembangkan untuk materi lainnya seperti, bahkan untuk mata pelajaran juga dapat menggunakan media ini. Misalkan mata pelajaran Bahasa Inggris yang nantinya harus disesuaikan dengan materi yang akan disampaikan dan mempersiapkan segala kelengkapan dalam menggunakan E-Komik ini sehingga berjalan lancar sesuai dengan yang sebelumnya di muat pada media ini yaitu Materi Persiapan Kemerdekaan Indonesia.

Simpulan penelitian pengembangan ini terdiri dari tiga hal yaitu pertama, rancang bangun penelitian pengembangan ini menggunakan model ADDIE yang terdiri dari 5 tahapan pengembangan dimulai dari tahap analysis (analisis), tahap design (perancangan), tahap depelovment (pengembangan), tahap implementation (implementasi), dan tahap evaluation (evaluasi).

Kedua, validitas dari E-komik Persiapan Kemerdekaan Indonesian mendapatkan presentase $95,83 \%$ dengan kualifikasi sangat memuaskan dari Ahli Desain Pembelajaran. Untuk validasi Ahli Media Pembelajaran mendapatkan presentase $93,75 \%$ dengan kualifikasi sangat memuaskan. Sedangkan uji coba perorangan memdapatkan presentase 95\% dengan kualifikasi sangat memuaskan, uji coba kelompok kecil mendapatkan presentase $93,05 \%$ dengan kualifikasi sangat memuaskan, dan uji ciba lapangan mendapatkan persentase $91,30 \%$ dengan kualifikasi sangan memuaskan. Jadi EKomik Persiapan Kemerdekaan Indonesia telah dimyatakan valid.

terakhir, efektifitas media didapatkan dengan melakukan uji-t dengan hasil yang menunjukkan thitung lebih besar dari ttabel yaitu $51,49>2,45$ sehingga $\mathrm{H} 0$ ditolak dan $\mathrm{H} 1$ diterima, Hal tersebut menunjukkan bahwa E-komik Persiapan Kemerdekaan Indonesia memberikan pengaruh kepada siswa terhadap hasil minat belajar dalam mempelajari persiapan kemerdekaan indonesia.

Beberapa saran yang dapat disampaikan dalam pengembangan E-komik Persiapan Kemerdekaan Indonesia ini adalah Siswa disarankan dapat memanfaatkan E-komik Persiapan Kemerdekaan Indonesia dengan baik dan benar. Selaiin itu siswa juga diharapkan untuk mterus meningkatkan rasa cinta terhadap tanah kita dan mengambil sifatsifat positif yang dapat ditiru dari para pahlawan kita.

Guru disarankan untuk menggunakan E-komik Persiapan Kemerdekaan Indonesia dalam pembelajaran dan juga membantu membagikan kepada guru lain guna mengatasi permasalahan yang sama dalam meningkatkan minat belajar siswa. 
Kepada kepala sekolah SD Negeri 5 Kampung Baru, disarankan mengadakan pelatihan bagi guru-guru, baik guru muda maupun yang sudah berumur. pelatihan ini selain guru mendapatkan pengetahuan dan keterampilan yg sesuai dengan perkembangan siswa.

Saran yang sampaikan kepada peneliti lain, agar dapat menggunakan hasil penelitian pengembangan ini sebagai refrensi dalam melakukan penelitian sejenis ataupun penelitian yang lebih kompleks yang meneliti minat belajar siswa ataupun Ekomik sebagai media pembelajaran.

Kepada teknolog pembelajaran lain disarankan agar lebih kreatif memanfaatkan kemampuan dan keterampilan yang didapat selama perkuliahan dalam mengembangkan media pembelajaran yang sesuai dengan perkembangan jaman,. Selain itu media pembelajaran adalah pelengkap dari proses pembelajaran agar tujuan dari pembelajaran dapat tercapai sepenuhnya.

\section{DAFTAR PUSTAKA}

Agung, A. A. G. 2014. Metodologi Penelitian Pendidikan. Buku Ajar Metodologi Pendidikan. Malang: Aditya Media

Agustiningsih. 2015. "Pengembangan Desain E-Komik Tematik Berbasis Pada Pendidikan Lingkungan Hidup Dengan Aplikasi Macromedia-Flash Untuk Kelas Permulaan Sekolah Dasar". Pancaran, Vol. 4, No. 4, hal 177-194.

Bintari, M. S. 2014. Pengembangan Komik Sebagai Sumber Belajar IPS Dengan Materi Konektivitas Antar Ruang Untuk Siswa Smp Kelas Vii. Skripsi (Tidak Pernah Di Terbitkan). Jurusan Pendidikan IImu Pengetahuan Sosial,Universitas Negeri Yogyakarta.

Darmawan, R. 2015. Pengaruh Minat Belajar Dan Perhatian Orang Tua Terhadap Prestasi Belajar Siswa Kelas Tinggi Sd
Negeri 01 Wonolopo Tahun Ajaran 2014/2015. Skripsi (diterbikan). Program Studi Pendidikan Guru Sekolah Dasar, Fakultas Keguruan dan IImu Pendidikan, Universitas Muhammadiyah Surakarta.

Djamarah, S. B. 2002. Psikologi Belajar. Jakarta: Rineka Cipta

Erwinsyah, A. 2015. "Pemahaman Mengenai Teknologi Pendidikan Dan Teknologi Pembelajaran". Tadbir Jurnal Manajemen Pendidikan Islam, Vol. 3, No 1, Issn 2338-6673

Gumelar, M. S. 2011. Comic Making. Jakarta: Indeks.

Mukminan. 2012. "Teknologi Pendidikan Untuk Peningkatan Kualitas Pembelajaran" Makalah Disajikan Dalam Seminar Nasional Teknologi Pendidikan. Prgram Studi S2 Teknologi Pendidikan, Universitas Tanjungpura ,Pontianak 9 November 2012.

Mahadewi dan Sukmana. 2015. Text-Based Programing. Yogyakarta : Graha IImu.

Sudjana dan Rivai. 2011. Media Pengajaran. Bandung: Sinar Baru Algesindo

Rasiman \& Pramasdyahsari, 2014. "Development of Mathematics Learning Media E- Comic Based on Flip Book Maker to Increase the Critical Thinking Skill and Character of Junior High School Students". International Journal of Education and Research, Vol. 2 No. 11.

Supriyanta, E.Y. 2015.” Pengembangan Media Komik Untuk Mata Pelajaran IImu Pengetahuan Sosial Tentang Sejarah Persiapan Kemerdekaan Indonesia Pada Kelas V Sd Muhammadiyah Mutihan Wates Kulon Progo".Skripsi (tidak Pernah di terbitkan). Jurusan Pendidikan Prasekolah Dan Sekolah Dasar, Universitas Negeri Yogyakarta. 
Slameto. 2010. Belajar dan Faktor-faktor yang Mempengaruhi. Jakarta: Rineka Cipta.

Sudarma, d.k.k., 2015. Desain Pesan Kajian Analitis Desain Visual Teks dan Image. Yogyakarta: Graha IImu.

Tegeh. I. Md. 2010. Media Pembelajaran. Singaraja: Universitas Pendidikan Genesha.

Tegeh, I. Md., dkk. Model Penelitian Pengeembangan. Yogyakarta: Graha IImu. 